\title{
ポリシロキサン三次元架橋体の開発と化粧品への応用
}

\section{Development and Cosmetic Application of Cross-linked Polysiloxane}

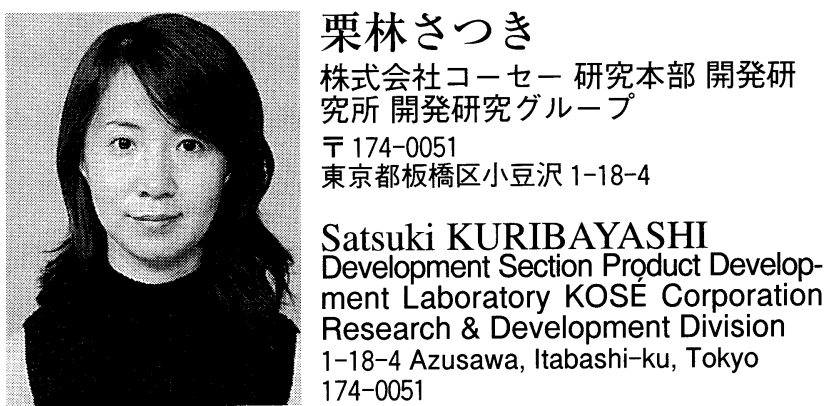

\begin{abstract}
Various kinds of oil which can keep our skin emollient are widely used in cosmetic formulations. It is technically important to make oil into a gelling state in order to improve stability of cosmetic products. Dimethylpolysiloxane has become popular recently, because it has unique properties, such as smooth and non-greasy touch and water repellency. However, oil gelling agents, particularly a gelling agent of dimethylpolysiloxane are less found in cosmetic ingredients.

Thus, the cross-linked polysiloxane which can swell in dimethylpolysiloxane forming a soft gel has newly been developed. Then modifying the above cross-linked polysiloxane made it possible to make oil, such as paraffins, esters, glycerides into a stable gel, and W/O type gel emulsions can also be obtained. In this paper, the structure and characteristics of the cross-linked polysiloxane are introduced together with some examples of cosmetic applications.
\end{abstract}

Key words: gelling agent, polysiloxane, cross-linking, oil, W/O type

\section{1 はじめに}

化粧品には，化粧水や乳液，クリーム，ファンデー ション, 口紅, マスカラ, マニキュア等, 様々な形態の 製品が存在する。これらの化粧品の製剤化技術とコロイ ド分散系とは切っても切り離せない。例えば, 油を水に 可溶化させるミセル形成, 粉体や顔料を水や油中に分散 させるサスペンション，水と油を安定化するエマルショ ン，ヘアスタイリングムースに応用されるエアゾール等 が基本的なコロイド分散系として挙げられる。

このようなコロイド分散系の安定化を図るためには， レオロジーの観点からも, 分散媒に構造粘性を付与し, ゲル構造にすることが重要な技術の一つとなる。また， 水や液体油などをゲル化することは, 化粧品において安 定性の向上のみならず，手にとるときの流動性や塗布時 ののび広がりの調整など，使用性，使用感の向上という 点からも，化粧品には重要な技術である。

現在，水系のゲル化剤としては，植物由来の多糖類な どの天然系水溶性高分子を始め, 澱粉誘導体やセルロー

連絡者：栗林さつき

E-mail : skuribayashi@kose.co.jp.
ス誘導体に代表される半合成系高分子，ビニル系ポリ マーやアクリル系ポリマーなどの合成高分子, モンモリ ロナイトやへクトライトなどの粘土鉱物等が，目的に応 じて使い分けられている。それに対して, 油のゲル化剤 としては，固形ワックスやデキストリン脂肪酸誘導体， 有機変性粘土鉱物などがあるが，水系のゲル化剤に比べ てその種類は少ない。従って，乳液やクリームの乳化製 剤も, 分散媒が油系の油中水型エマルション（以下, $\mathrm{W} / \mathrm{O}$ エマルションと略する）は，分散媒が水系の水中 油型エマルション（以下， O/W エマルションと略する） に比べ多用されていない原因の一つであった。

ところで，化粧品には様々な油剂が使用されている。 例えば，炭化水素油は乳化しやすく，皮膚に対して疎水 性の皮膜をつくるため，皮膚からの水分蒸散を防ぐなど の特徵があり，またエステル油やグリセライド油は，そ の構造より，低極性から高極性まで幅広い極性を持つた め皮膚に対して親和性があり，柔軟性，エモリエント感 を付与し，他の化粧品原料の極性成分と無極性成分の相 互親和成分として働くなど，目的とする感触や殽型にあ わせて選択され使用されている。

また近年，油剤として直鎖および環状のジメチルポリ 
シロキサンが汎用化されている。ジメチルポリシロキサ ンは, べたつきのないさっぱりした使用感, 軽いのび広 がり，そして高い撥水性などの特長を有するが，その反 面, 他の一般油剤との相溶性がそしい。さらに, ジメチ ルポリシロキサンをゲル化する技術は，これまで開発さ れてなかったため，化粧品への配合量が制限されるな ど，製剤化技術の制約となっていた。

そこで，我々は先ず，ポリシロキサン鎖を三次元的に 架橋することで, ジメチルポリシロキサンに構造粘性を 付与するゲル化㓱の開発を行った。次に, この三次元架 橋体をべースに親水性を付与する検討を行い，さらにア ルキル基の導入によりジメチルポリシロキサン以外の油 剤もゲル化できるよう，展開を図った。

本稿では, これらのゲル化剂開発の検討経過について 順を追って説明すると共に, 実際の化粧品への応用例に ついても紹介する。

\section{2 ポリシロキサン構造をもつゲル化剤について}

\section{$2 \cdot 1 \quad$ ポリシロキサンの性質}

ポリシロキサン鎖を主体とするゲル化剤の開発にあた り，まず骨格となるシロキサン結合の特徴をおさえてお く必要がある。

まず，ケイ素と炭素は周期律表で同じ 14 族に属して おり，両者とも 4 本の結合手を持っているが，ポリシロ キサン鎖の骨格をなすシロキサン結合は，炭素一炭素結 合と比較して次のような相違点がある。

(1)シロキサン結合 (-Si-O-Si-) の結合エネルギー $\left(4.44 \times 10^{5} \mathrm{~J} / \mathrm{mol}\right)$ は, 炭素結合 $(-\mathrm{C}-\mathrm{C}-\mathrm{C}-)\left(3.56 \times 10^{5}\right.$ $\mathrm{J} / \mathrm{mol})$ や，エーテル結合 $(-\mathrm{C}-\mathrm{O}-\mathrm{C}-)\left(3.39 \times 10^{5} \mathrm{~J} / \mathrm{mol}\right)$ よりも大きく安定である。

(2)炭素結合は $100 \%$ 共有結合であるのに対し，シロキ サン結合は $50 \%$ のイン結合性を有し，有機と無機の 中間の性質を有する。

(3)シロキサン結合は炭素結合に比べ，結合間距離が長 く, 相対電子密度が低いことから, 結合の回転が容易で ある。

従って，シロキサン結合を持つポリシロキサン鎖の性 質は，炭素結合に比べ屈曲性に富んでいて柔軟で，無機 材料の耐熱性と, 有機材料の反応性, 溶解性等を兼ね備 えた材料であると言える。そのため, 種々の有機基の導 入が可能で, その有機基の変性率, 骨格の構造, 分子量 を変えることにより, 様々な変性ポリシロキサン化合物 （オルガノポリシロキサン）の合成が可能である。1)

\section{$2 \cdot 2$ ゲル化剤について}

従来使用されている，ワックスなどの油剤のゲル化剂 は, その構造性, 化学的性質より固体状のゲル（ハード
ゲル）を形成し，化粧品にとって好ましいソフトな感触 のゲルをつくるには適さない。そこで, 柔軟性のあるポ リシロキサンを主鎖として, ポリシロキサン鎖間を橋か けして三次元の網目構造を形成させれば，従来にはない 機能と官能を持つゲル化剤の設計が可能であると考えた。

実際に，ポリシロキサン鎖を橋かけする架橋剤の種 類，あるいは側鎖の官能基を検討することで，ジメチル ポリシロキサンのみならず，他の油剤（炭化水素油，エ ステル油, グリセライド油）と親和性を持ち，安定で, 柔軟性に優れたソフトゲルを形成するポリシロキサン三 次元架橋体（以下，ポリシロキサン架橋体と省略する） が得られた。

以下に，これらポリシロキサン架橋体について詳しく 触れていくことにする。

\section{3 ポリシロキサン架橋体の開発}

\section{$3 \cdot 1$ ポリシロキサン架橋体の合成とその特性}

ポリシロキサン架橋体の主鎖には, Fig. 1 に示すメチ ルハイドロジェンポリシロキサンを用いた。このポリシ ロキサンは分子中に反応性の $\mathrm{Si}-\mathrm{H}$ を有するため, 水酸 基を有する有機化合物との脱水素縮合反応や，アルケニ ル基を有する有機化合物との付加反応が可能である。

この反応性を利用し，4タイプのポリシロキサン架橋 体（サンプル 1〜4）を得た。

\section{$3 \cdot 1 \cdot 1$ 合 成}

サンプル 1 の架橋体は, メチルハイドロジェンポリシ ロキサンをアルカリ触媒下で縮合反応を行い合成した。

サンプル 2 及び 3 の架橋体は，メチルハイドロジェン ポリシロキサンに, 架橋剤として両末端ビニル変性ジメ チルポリシロキサンを加え, 白金触媒下で付加反応を行 い合成した。

サンプル 4 の架橋体は, メチルハイドロジェンポリシ ロキサンに, 架橋剤として両末端ビニル変性メチルフェ ニルポリシロキサンを加え, 白金触媒下で付加反応を行 い合成した。

\section{$3 \cdot 1 \cdot 2$ ポリシロキサン架橋体の特性}

Table 1 には，それぞれのポリシロキサン架橋体の構 造および特性についてまとめて示す。

サンプル 1 は, 主鎖同士がもっとも短い単位シロキサ

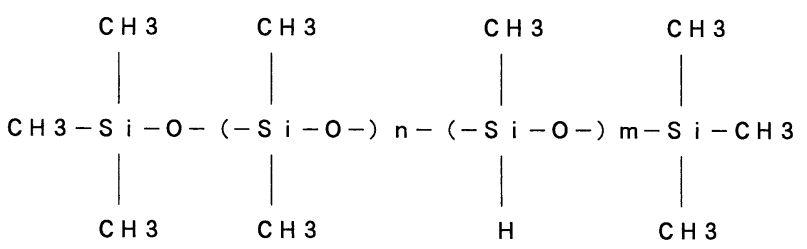

Fig. 1 Structure of Methylhydrogenpolysiloxane. 
Table 1 Structure and Characteristics of Several Cross-linked Polysiloxanes.

\begin{tabular}{|c|c|c|c|c|}
\hline & サンプル 1 & サンプル 2 & サンプル 3 & サンプル 4 \\
\hline 反応タイプ & 縮合反応 & 付加反応 & 付加反応 & 付加反応 \\
\hline 架橋 構 造 & $\begin{array}{l}\text { シロキサン } \\
\text { 結合 }\end{array}$ & $\begin{array}{l}\text { ジメチルポリ } \\
\text { シロキサン }\end{array}$ & $\begin{array}{l}\text { ジメチルポリ } \\
\text { シロキサン }\end{array}$ & $\begin{array}{l}\text { メチルフェニル } \\
\text { ポリシロキサン }\end{array}$ \\
\hline $\begin{array}{l}\text { 架橋部分の } \\
\text { 平均分子量 }\end{array}$ & - & 1000 & 10000 & 6000 \\
\hline $\begin{array}{l}\text { ゲル化可能 } \\
\text { な 油 剤 }\end{array}$ & $\begin{array}{l}\text { •ジメチル } \\
\text { ポリシロキサン }\end{array}$ & $\begin{array}{l}\text { •ジメチル } \\
\text { ポリシロキサン }\end{array}$ & $\begin{array}{l}\text { •ジメチル } \\
\text { ポリシロキサン }\end{array}$ & $\begin{array}{l}\text { ·ジメチル } \\
\text { ポリシロキサン } \\
· \text { •メチルフェニル } \\
\text { ポリシロキサン } \\
\text { ·エステル油 }\end{array}$ \\
\hline
\end{tabular}

ン結合 (-Si-O-Si-) で架橋され, 三次元架橋構造が形 成される。この架橋体は, 主鎖のポリシロキサン鎖と親 和性が高い，ジメチルポリシロキサンをゲル化すること ができる。

サンプル 2 及びサンプル 3 は，ポリシロキサン主鎖 で，架橋部分がジメチルポリシロキサン構造のものであ る。

ただし，サンプル 2 に比ベサンプル 3 の方が架橋のジ メチルポリシロキサンの平均分子量が大きい（架橋部分 が長い)。これらの架橋体も，サンプル 1 と同様，ジメ チルポリシロキサンをゲル化することができる。

Fig. 2 には，ジメチルポリシロキサンをサンプル 1～3 でゲル化したゲル組成物を示す。いずれも，ゲル組成物 の粘度が $3.0 \times 10^{4} \mathrm{mPa} \cdot \mathrm{s}$ に成るように調製したサンプル である。サンプル 1 の架橋体の配合量は $25 \%$ ，サンプ ル 2 は $18 \%$, サンプル 3 は $5 \%$ である。

架橋部分のシロキサン結合が長鎖化するにつれ，ゲル の透明性が高くなっていることが分かる。これは，溶媒 のジメチルポリシロキサンが，主鎖のポリシロキサンと の親和性に加え, 架橋部分のジメチルポリシロキサンと の親和性が高まり，架橋体の膨潤性が向上しているため

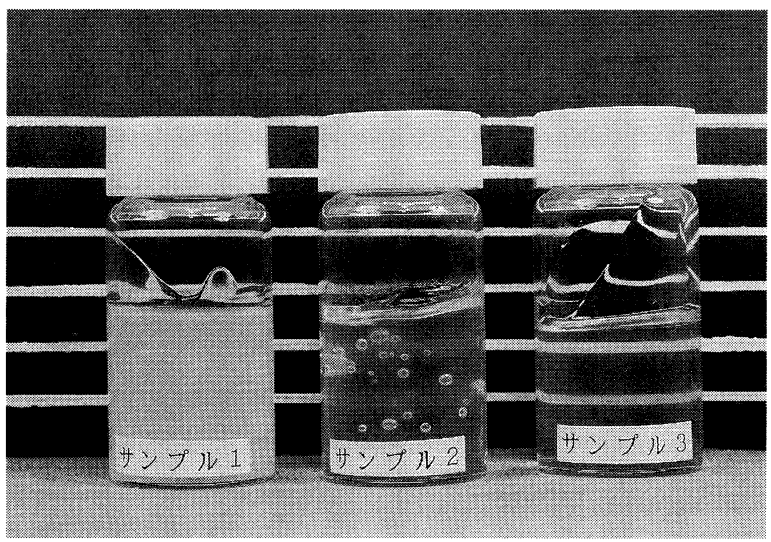

Fig. 2 Dimethylpolysiloxane Gel Prepared by the Various Cross-linked Polysiloxanes. (sample $1 \sim 3$ )
と考えられる。従って、架橋体量が少ない濃度で, 効果 的にゲル化できることが分かった。また，この架橋体 は，屈曲性に富み柔軟性のあるポリシロキサンが主体と なっているため，この架橋体が膨潤したジメチルポリシ ロキサンはソフトゲルを形成する。

サンプル 4 は，ポリシロキサン主鎖で，架橋部分がメ チルフェニルポリシロキサン構造のものである。メチル フェニルポリシロキサンは極性のあるフェニルを有する ため，エステル油との相溶性も高い。従って，ジメチル ポリシロキサンの他に，メチルフェニルポリシロキサン やエステル油をゲル化することが可能である。

サンプル 1〜4のように, 架橋構造の種類や架橋部分 のシロキサン結合の長さを変えることにより，ジメチル ポリシロキサンやエステル油のゲル化剤を開発すること が可能になった。これらのポリシロキサン架橋体の外観 は, Fig. 3 に示すようにスポンジ状の弾力性のある固体 の形状をしている。これを親和性のある油剤で希釈して ロールミルで混練すると, Fig. 4 に示すようなソフトゲ ルが得られる。

以上のゲル化剂の開発により，ジメチルポリシロキサ ンやエステル油のソフトゲル化が可能になり，化粧品剤 型の幅がひろがり新たな機能を持った製品開発に結びつ

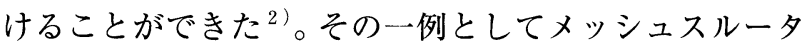

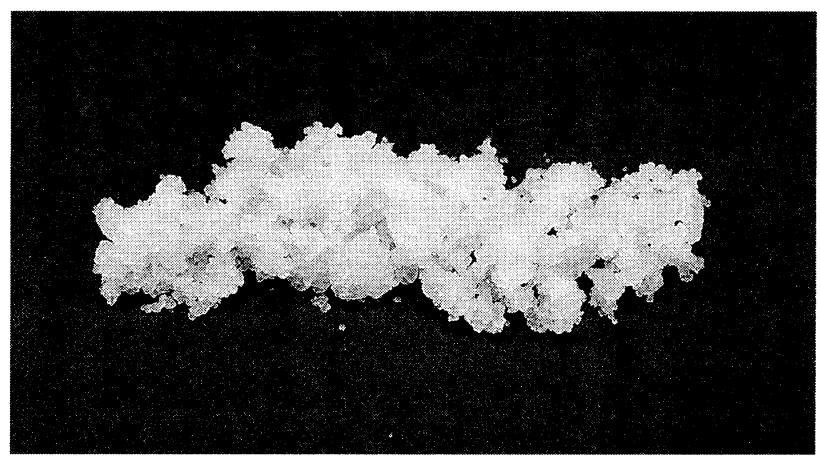

Fig. 3 Appearance of the Cross-linked Polysiloxane.

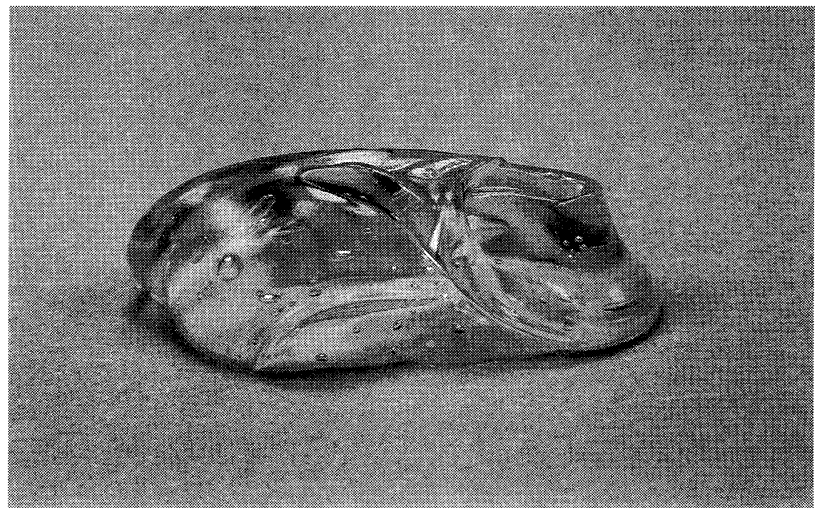

Fig. 4 Oil Gel Prepared by the Cross-linked Polysiloxane. 
イプの油性ファンデーションを紹介する。

$3 \cdot 2$ メッシュスルーコンパクトファンデーションの開 発

油性ファンデーションは, 油剤のなかに顔料や粉体を 分散し, ワックスで固めたタイプのファンデーションで ある。この剤型は，油剤量が多いため耐水性に優れ，工 モリエント効果が高く，また肌の欠点（しみ，ソバカ ス）を隠すカバーカのある仕上がりが特徽であるが，反 面, 油っぽさやべたつき, のび広がりの悪さ, また化粧 もちに関しても，塗布後，時間がたつと皮脂と馿染んで ムラや油光りする（テカリ）など，化粧もちが悪いとい う欠点があった。そこで，ジメチルポリシロキサンを配 合してのびを軽くし，油っぼさの少ない仕上がりにする 検討を試みていたが，ジメチルポリシロキサンは他の油 剂との相溶性が悪く，また適当なゲル化剂がなかったた め, 製品化が困難であった。

しかし，ポリシロキサン架橋体が開発され，ジメチル ポリシロキサンやエステル油のゲル化が可能になったた め，製品へ安定に配合できるようになった。また，本架 橋体は固体であり，肌上にファンデーションを塗った時 の化粧膜が，油剤の膜の中に三次元架橋体が分散された 形となって光を拡散し，油光り（テカリ）を防止する効 果もみられた。

ソフトゲルを形成する本架橋体で構造性をもたせた油 性ファンデーションは，ワックスゲルで固形化したもの

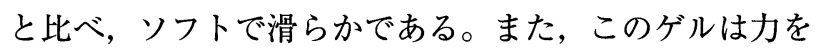
加えたとき構造が一時的に破壊して流動性をもち, 放置 すると構造が復帰するチキソトロピー性を持つことが確 認されている。この性質を応用して，ファンデーション の表面にメッシュを配し，スポンジでファンデーション をとる際，ソフトゲル状のファンデーションがメッシュ の隙間を通ることで構造が壤れ, 液状ファンデーション に変化するという，メッシュスルータイプのコンパクト ファンデーションの開発に至った。

更に，これらのゲル化剤は，クレンジング，クリー ム，サンケア化粧料など様々な㑉型に広く応用されてい る。

\section{4 部分親水化ポリシロキサン架橋体の開発}

\section{$4 \cdot 1$ 含水性を有する部分親水化ポリシロキサン架橋体 の合成とその特性}

次に, 油ゲル化剂としての機能に加え, 含水能を付与 する目的で，親水基のポリオキシエチレン鎖を導入し， ポリシロキサン鎖とポリオキシエチレン鎖からなる三次 元架橋体の合成を行った。その結果, ジメチルポリシロ キサンをゲル化すると共に，ゲル化剤自身が水との親和

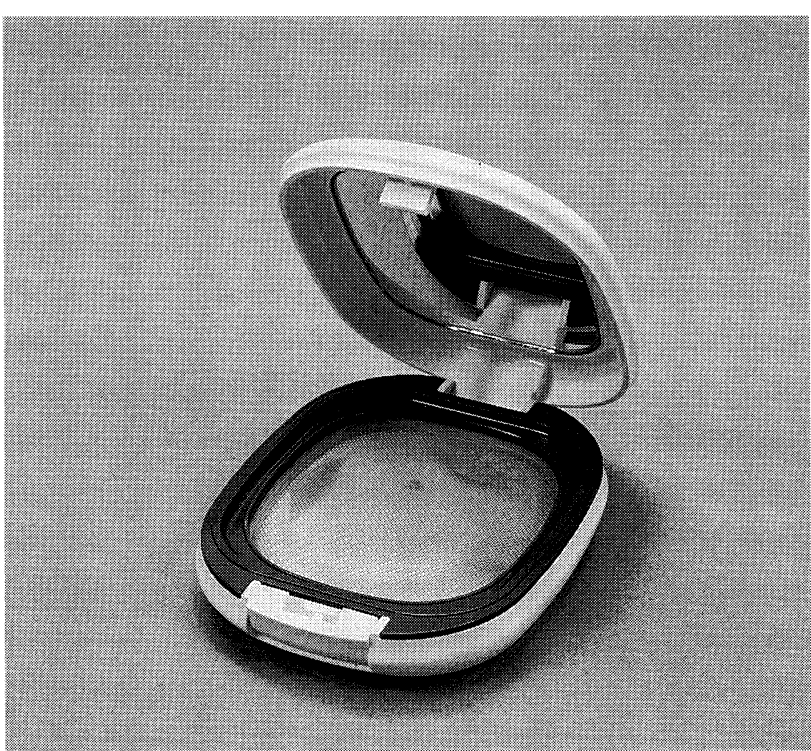

Fig. 5 Oil Type Foundation Containing the Cross-linked Polysiloxane.

性を持ち, 容易に W/O タイプの安定な油性ゲルを形成 するという，ユニークな特徵が観察された。

そこで, ゲル組成物の流動特性とそのゲル化機構の考 察を行い，次にポリオキシエチレン鎖を導入したことに より新たな機能として付与された, 乳化特性について検 討を行った。

\section{$4 \cdot 1 \cdot 1$ 合 成}

部分親水化ポリシロキサン架橋体は，主鎖のメチルハ イドロジェンポリシロキサンに架橋剤としてポリオキシ エチレンジアリルエーテルを加え，白金触媒下で付加反 応を行い合成した。

\section{$4 \cdot 1 \cdot 2$ 流動特性}

部分親水化ポリシロキサン架橋体は，前述の架橋体と 同様，ロールミルを用い，高せん断力下でジメチルポリ シロキサンと混練することにより，ゲル組成物を形成す る。この架橋体の濃度が異なるゲル組成物を調製し，各 濃度で測定したレオロジーの結果を Fig. 6 に示す。

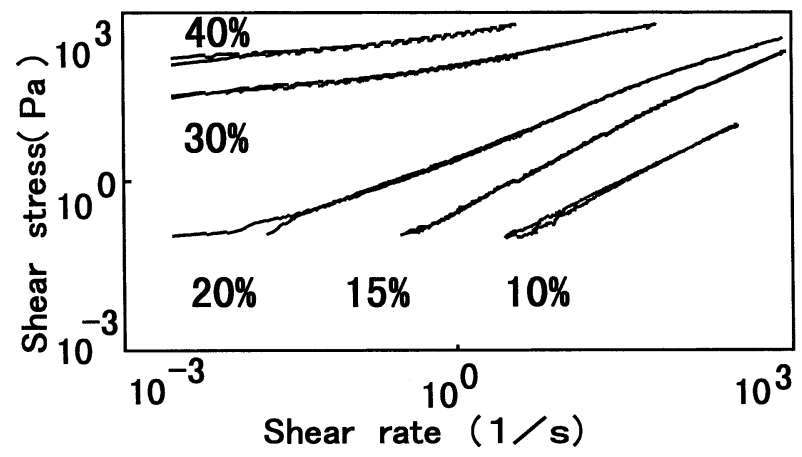

Fig. 6 Shear Rate Dependence of Shear Stress for Each Gel Containing Different Concentrations of the Partially Hydrophilic Cross-linked Polysiloxane. 
以上の結果より, この部分親水化ポリシロキサン架橋 体は, 濃度が $20 \%$ 以上では降伏值を持つゲルを形成し ていることが分かる。濃度 15\%以下では, その流動特 性はニュートン流動を示し, さらに希釈した低濃度領域 では, 微粒子状固体の沈降が観察された。ここで, 高濃 度では均一なゲルを形成するが, 低濃度で, 低粘度領域 において微粒子が沈降していることから, 本架橋体は微 粒子であることが予測された。

これらの現象よりゲル化の機構としては, 部分親水化 ポリシロキサン架橋体がジメチルポリシロキサンをゲル 化するとき, まず, 架橋体粒子が溶媒のジメチルポリシ ロキサンとの相互作用により膨潤する。そして, 架橋体 粒子が高濃度に存在して分散している場合, 互いの膨潤 した粒子が近接することで粒子の表面ポリシロキサン鎖 どうしが絡み合い, ネットワーク構造を形成し，安定な ゲル構造をつくると考えられる。また, 希釈されて, 架 橋粒子が希薄濃度となったとき, この架橋体粒子同士の 粒子間距離が長くなり, ポリシロキサン鎖同士の絡み合 いがなくなるため，ネットワーク構造を作ることができ ず，ゲルを形成できない。従って，架橋体粒子が沈降し たと考えられる。

そこで，この架橋体粒子の確認を実施した。まず，合 成して得られた架橋体をアセトンで希釈し，不溶部分と して沈降した架橋体粒子を取り出し，粒度分布の測定を 行った。その結果を Fig. 7 に示す。

以上の結果から, 部分親水化ポリシロキサン架橋体 は, 平均粒径 $10 \mu \mathrm{m}$ 程度の微粒子であることが分かっ た。また, そのゲル化機構は, 架橋体とジメチルポリシ ロキサン，そして架橋体同士の相互作用による絡み合い であることが示唆された。

\section{$4 \cdot 1 \cdot 3$ 乳化特性}

部分親水化ポリシロキサン架橋体は, ジメチルポリシ ロキサンと混錬して調製したゲルに水を攪拌しながら添

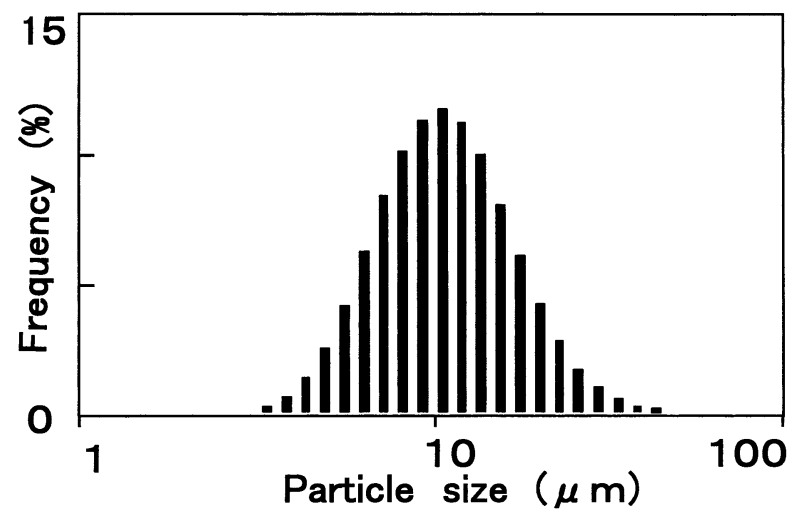

Fig. 7 Particle Size Distribution of Insoluble Part of the Partially Hydrophilic Cross-linked Polysiloxane.
加した場合, 水を内相, ジメチルポリシロキサンを外相 とする $\mathrm{W} / \mathrm{O}$ エマルションが得られる。本架橋体, ジメ チルポリシロキサン，そして水の三成分からなる乳化領 域を示した状態図を Fig. 8 に示す。

Fig. 8 の右端に, 部分親水化ポリシロキサン架橋体と ジメチルポリシロキサンが少量の水を含水して透明 I 相 になる領域が，わずかに存在することが観察された。そ の他の広範囲の領域では, $\mathrm{W} / \mathrm{O}$ エマルションが得られ ることが分かった。また，この領域の W/O エマルショ ンは各温度（5,15,30 及び $40^{\circ} \mathrm{C} ）$ においていずれも安定 で, エマルションの凝集や合一, そして排液や分離も見 られなかった。

Fig. 9 は, 三成分系状態図の A 点（架橋体 $2 \%$, ジメ チルポリシロキサン $3 \%$ ，水 $95 \%$ ）の組成からなる $\mathrm{W} / \mathrm{O}$ エマルションの顕微鏡写真である。このように, 本架 橋体を用いた $\mathrm{W} / \mathrm{O}$ エマルションは, その乳化滴（水

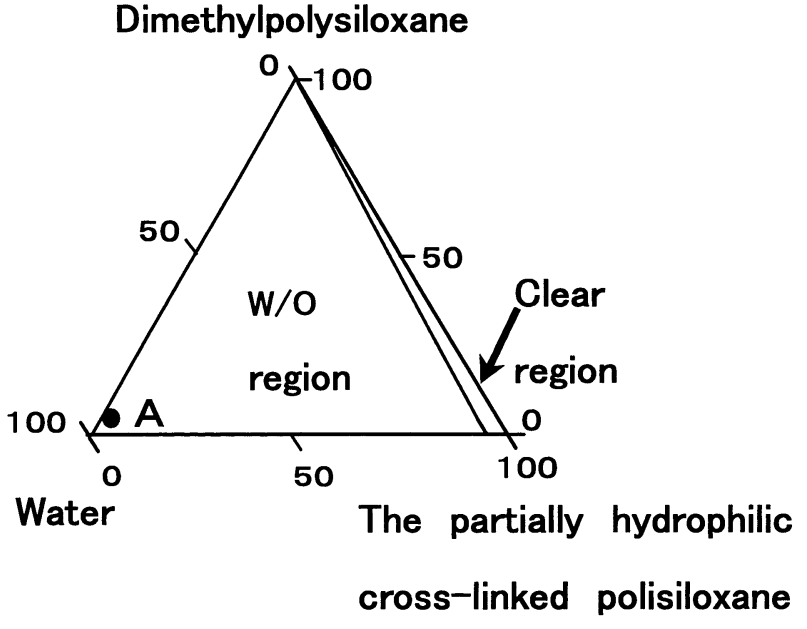

Fig. 8 Phase Diagram for the Three-component System : the partially hydrophilic cross-linked polysiloxanewater-dimethylpolysiloxane.

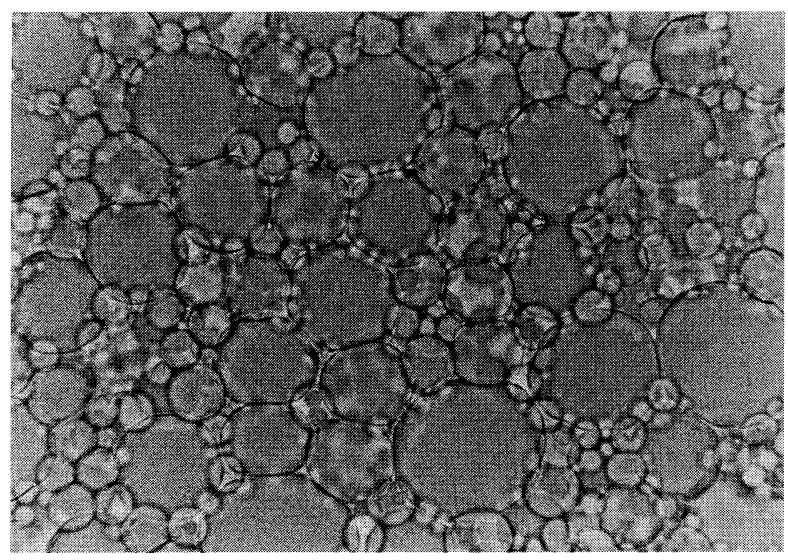

Fig. 9 Microphotograph of the W/O Emulsion Prepared Using the Partially Hydrophilic Cross-linked Polysiloxane. 
相）が不均一で, 歪んだいびつな形状のものも見られ， その粒径は 5〜20 $\mu \mathrm{m}$ と大きいことが分かった。

次に, 水とジメチルポリシロキサンの間の界面張力に ついて測定した。ジメチルポリシロキサンと部分親水化 ポリシロキサン架橋体を濃度を変えて混練し, 水との界 面張力をペンダントドロップ法により測定した。結果を Fig.10に示す。

比較のため, ポリシロキサン系の $\mathrm{W} / \mathrm{O}$ 乳化剂として 化粧品に多く使用されている，ポリオキシエチレン・メ チルポリシロキサン共重合体の界面張力も併せて測定を 行った。その結果, 部分親水化ポリシロキサン架橋体は ポリオキシエチレン・メチルポリシロキサン共重合体と 比べ，界面張力低下効果が低いことが判明した。

$\mathrm{W} / \mathrm{O}$ エマルションは，水が油中に分散した系であり， 熱力学的には不安定な系である。W/Oエマルションの凝 集や合一を防ぎ, 安定性を確保するには, 界面張力低下 効果の高い活性剤を選択し、界面に効率よく配向させて 界面自由エネルギーを低下させ，均一で微細なエマル ション（数 $\mu \mathrm{m}$ 程度の大きさ）にする必要があった。こ れに対し、本架橋体は微粒子であり, 界面張力低下効果 も低いことから, 界面自由エネルギーがポリシロキサン 系の $\mathrm{W} / \mathrm{O}$ 乳化剂と比べて大きく、従って粒径の大きい エマルションができると考えられる。

また，本架橋体はジメチルポリシロキサン中で膨潤 し，膨潤した粒子同士がネットワーク構造を形成してゲ ル化する。そして柔軟で温度依存性の小さいシロキサン 結合の為, 高温領域でも, 粒径の大きいエマルションが 凝集や合一, クリーミングをおこすことなく安定に保つ ことができると考えられた ${ }^{3)}$ 。

\section{$4 \cdot 2$ 高含水型 W/O クリームの開発}

前述したように、水のゲル化剂に比べ油ゲル化剂は種 類が少ないため、化粧品において W/Oエマルションの 乳化製荗は数少ないのが現状であった。そこで，今回開

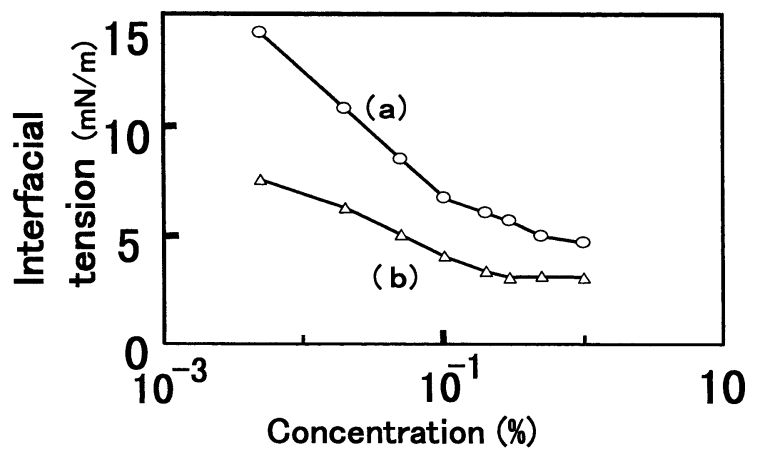

Fig.10 Interfacial Tension between Water and Dimethylpolysiloxane Containing (a) : the partially hydrophilic cross-linked polysiloxane (b) : polysiloxane type W/O emulsifier.
発した，部分親水化ポリシロキサン架橋体を応用した $\mathrm{W} / \mathrm{O}$ 型クリームの検討を行ったところ，今までに無い 新しい感触, 使用感が得られることが分かった。

従来の $\mathrm{W} / \mathrm{O}$ 乳化剂を使用した $\mathrm{W} / \mathrm{O}$ 型クリームは, 均一で微細なエマルションを持つために，肌にのばす と，まず外相の油剤が連続相となってのび，さらに手で なじませていくとエマルションの構造が破壊し内相の水 が出てくる。この時, 油膜の中に小さな水滴が分散した 形で構造性をもったままのばしていくため，使用感とし ても油っぽさ，重さを感じ，且つエマルションが壊れて も，みずみずしさが感じられなかった。

しかし, 部分親水化ポリシロキサン架橋体を応用した $\mathrm{W} / \mathrm{O}$ 型クリームは，含水量が高く，内水相が粒径の大 きいエマルションで存在し，肌にのばすときの力で水が はじきだされ水滴となる。

以上の技術を応用した高含水型 $\mathrm{W} / \mathrm{O}$ クリームは, 肌 に塗布する力を加えたときダイナミックな構造の変化を 起こし，軽いのび，みずみずしさを感じるものとなっ た。また，ジメチルポリシロキサンの持つべたつきのな

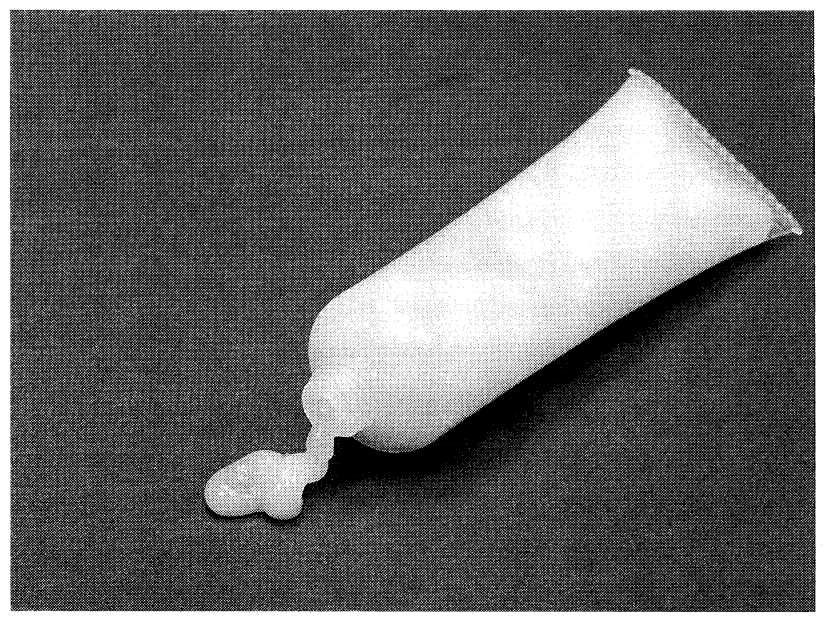

Fig. 11 High-internal-phase-ratio W/O Type Cream.

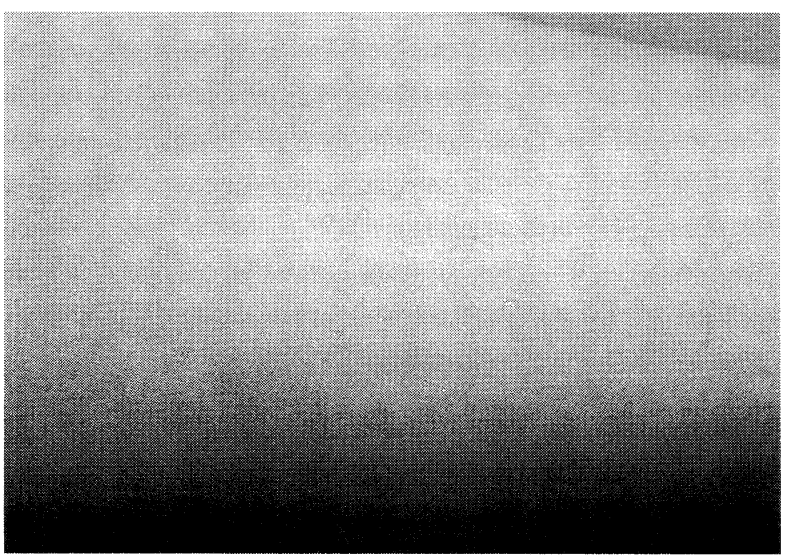

Fig. 12 The State of the High-internal-phase-ratio W/O Type Cream Applied to the Skin. 
いさっぱりした使用感, 軽いのび広がり, そして高い撥 水性など, 新しい感触と機能を持ち合わせた化粧料の開 発に至った。

また，部分親水化ポリシロキサン架橋体は，この特異 な性質を生かして, 水を配合したリップスティックや ファンデーション, $\mathrm{O} / \mathrm{W} / \mathrm{O}$ エマルションなど, 新たな 技術として応用されている。

\section{5 アルキル変性部分親水化ポリシロキサン架橋体の開 発}

\section{$5 \cdot 1$ アルキル変性部分親水化ポリシロキサン架橋体の 合成とその特性}

今まで述べてきた, ポリシロキサン架橋体, 及び部分 親水化ポリシロキサン架橋体はポリシロキサン鎖が主鎖 であったため, ゲル化の可能な油剤としてはジメチルポ リシロキサンが中心であった。化粧品には, ジメチルポ リシロキサン以外にも，のびの良さ，エモリエント等の 肌効果を付与するため, 炭化水素油, エステル油, グリ セライド油など多く油剂が配合されている。そこで，ジ メチルポリシロキサン以外のこれらの油剤をゲル化でき る三次元架橋体の検討を行った。

具体的には，部分親水化ポリシロキサン架橋体の主鎖 の部分に, 炭化水素と親和性を持たせるためにアルキル 基を導入したものを合成し, 炭化水素油, エステル油, グリセライド油で化粧品に汎用されている流動パラフィ ン, イソオクタン酸セチル, トリイソオクタン酸グリセ リル（以下，LP，IOC，TIOG と略する）を選択し，こ れらの油剤に対するゲル化について検討した。

\section{$5 \cdot 1 \cdot 1$ 合 成}

アルキル変性部分親水化ポリシロキサン架橋体は, 側 鎖にアルキル基を有するメチルハイドロジェンポリシロ キサンを主鎖にして, 架橋剤としてポリオキシエチレン ジアリルエーテルを加え, 白金触媒下で付加反応を行い 合成した。

\section{$5 \cdot 1 \cdot 2$ アルキル鎖長によるゲル化能の検討}

ここで，側鎖に導入するアルキル基の炭素鎖長の違い による各油剤のゲル化能を, 架橋体 $20 \%$ のときの粘度 を測定することで, 比較検討を行った。その結果を Fig.13に示す。

以上の結果より，アルキル鎖長が長くなるにつれて， 同じ架橋体濃度の時の粘度は高くなり, ゲル化能は増し ていることが分かった。アルキル基が長くなるにつれ て, 油剤との親和性が増し, 膨潤性が向上するためと推 察される。ここで, 炭素数 12 のラウリル基を変曲点に, 特に無極性の LP においてその増粘性が頭打ちになって いることが分かる。

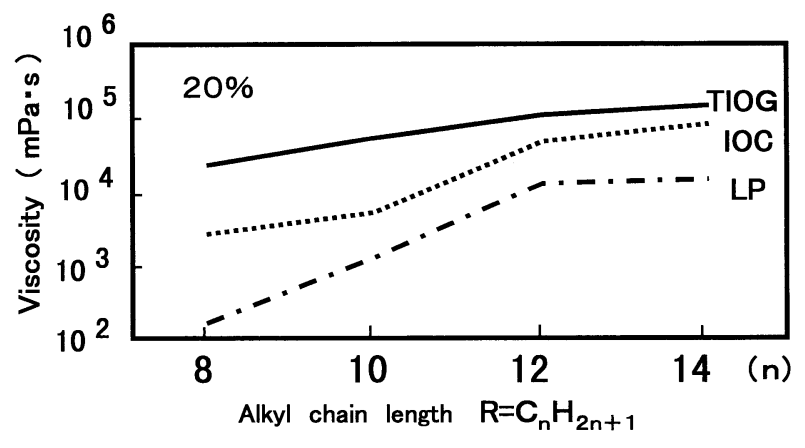

Fig. 13 Effect of Alkyl Chain Length of the Partially Hydrophilic Cross-linked Alkyl Polysiloxane on the Gel Viscosity.

また, IOC, TIOG と極性が高い油剤ほどゲル強度が 高い。これは，油剤の極性が高くなるにつれ架橋体との 親和性が増し，膨潤性が良くなったためと考えられる。

そこで，導入するアルキル鎖長を炭素数 12 のラウリ ル基に固定し，架橋するポリオキシエチレン鎖の導入量 （親水性一親油性バランス）の検討を行った。

\section{$5 \cdot 1 \cdot 3$ ポリオキシエチレン鎖の導入量の検討}

架橋凪のポリオキシエチレンジアリルエーテルの導入 量を変えて,アルキル変性部分親水化ポリシロキサン架 橋体の HLB（計算值 HLB = ポリオキシエチレン量 /分 子量 $\times 20 ）$ が 2 3 になるようにコントロールしたサン プルを合成し，その含水能の検討を行った。その結果を Fig.14に示す。

このグラフは，架橋体 $1 \mathrm{~g}$ を含む油剤（LP） $10 \mathrm{~g}$ に対 し，安定に配合できる水系量のデータである。以上の結 果より, HLB が高くなるにつれ, 水との親和性が増し, HLB が 3 のとき, 油系に対して 10 倍以上の水を安定に 配合することができた。

また，このアルキル変性部分親水化ポリシロキサン架 橋体と水と LP の三成分状態においても, 部分親水化ポ リシロキサン架橋体同様, 幅広い $\mathrm{W} / \mathrm{O}$ 乳化領域を示し た。

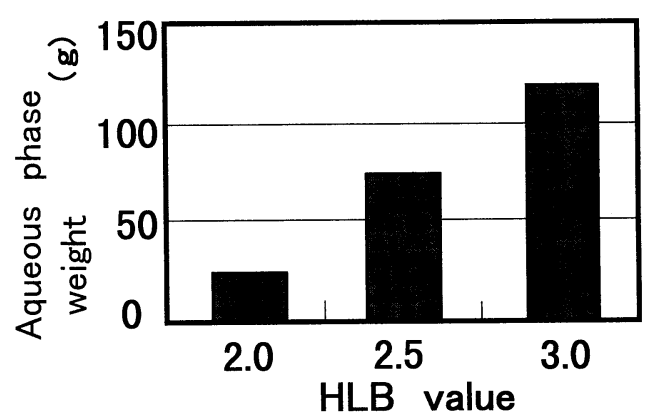

Fig. 14 Effect of HLB Value of the Partially Hydrophilic Cross-linked Alkyl Polysiloxane on Aqueous Phase Weight. 


\section{6 おわりに}

シロキサン結合をもつポリシロキサンを主鎖とし，そ れを架橋することでソフトゲルを形成するゲル化剤の開 発を行った。また, 架橋の長さ, 架橋剤の種類, そし て，側鎖への有機基を導入することで，炭化水素やエス テルの一般油剤から，ジメチルポリシロキサンまで幅広 い極性を持つ油剤をゲル化し, 安定性を保つことが可能 となった。さらに，親水基であるポリオキシエチレン鎖 で架橋することで，新たな特性をもった含水ゲル化剛を 開発することができた。これらは，ポリシロキサンの持 つ屈曲性に富んでいて柔軟で, 化学的に安定で, 有機材 料としての反応性，溶解性等を兼ね備えたという性質を 充分生かした素材であると言える。

この他にも，アクリル樹脂にポリシロキサン鎖を導入 した皮膜形成片や，ポリシロキサン樹脂粉体など，シロ キサン結合のもつ特性を生かして，新たな機能を付与し た素材の開発も行っている。また，今回の開発したソフ トゲル化剤のみならず，化粧品に高機能，高付加価值を
与えるような新素材を開発していくうえで，今後もさら にポリシロキサンが化粧品原料の骨格として展開されて いくことが考えられる。

更に，最近はジメチルポリシロキサンの他に化粧崩れ 防止効果の高い素材として，撥水性のみならず撥油性の 高いフッ素系油剤等も化粧品に配合されるようになり， これらフッ素系の原料開発もますます盛んになってくる ことが予想される。

今後も, 新しい機能, 特性, そして新しい形態の化粧 料に結びついていくような化粧品原料の探索を，積極的 に進めていきたいと考えている。

\section{文献}

1）伊藤邦雄編，(1990) シリコーンハンドブック，p.7, 日刊 工業新聞社.

2) 中林治郎，横大路清美，(1994）フレグランスジャーナ ル, 22, p.22.

3）野村利夫，横大路清美，作田晃司，(1999) J. Soc. Cosmet. Chem. Jpn., 33, p.134. 


\title{
餐合論文 ポリシロキサン三次元架橋体の開発と 化粧品への応用
}

\author{
栗林さつき \\ 株式会社コーセー研究本部 開発研究所 開発研究グループ（テ 174-0051 東京都板橋区小豆沢 1-18-4）
}

化粧品には，皮膚に柔軟性を与える等の目的で，様々な液体油が広く応用されている。これらの液体油をゲル化し， 構造粘性を付与することは, 化粧品製剤の安定化のためにも非常に重要な技術である。また近年は, 油剤としてジメ チルポリシロキサンが沉用されている。このジメチルポリシロキサンは, 油っぽさや゙たつきがなく, 且つ軽いのび, 高い撥水性などの特長を有する油剤である。しかしながら, これら液体油のゲル化澈, 特にジメチルポリシロキサン のゲル化剂は数が少なく，化粧品に安定に配合することは困難であった。

そこで，我々は新たに，ジメチルポリシロキサン中で膨潤してソフトゲルを形成する，ポリシロキサン三次元架橋 体を開発した。また，これらの架橋体に化学的修飾を行うことで, ジメチルポリシロキサン以外の油凨, 例えば炭化 水素油，エステル油，グリセライド油に対してのゲル化剤や，W／O型ゲルエマルションをつくることができた。

本稿では，これらいくつかのポリシロキサン三次元架橋体の構造とその特性，そして化粰品への応用例を紹介する。

(連絡者：栗林さつき) Vol.1, No.3, 247 (2001)

\section{縔合諞文 化粧品におけるスキンケア製剂の役割}

\section{岩井秀隆}

\section{花王株式会社 スキンケア研究所}

化粧品における製剤の役割は皮膚の保湿にあり，適切な感触に調整される。W/O 型， $\mathrm{O} / \mathrm{W}$ 型が一般的であり，使 用感で使い分けされてきたが，近年は様々な乳化製剂が開発され，その使い分けはあいまいになってきた。皮膚の保 湿は単に水の供給によるのではなく，天然保湿因子成分，皮脂，七ラミドをバランスよく角層に供給しなければなら ない。従って，これらを含有したスキンケア化粧料が必要となる。最近は皮膚科学研究の発展が著しく, 肌の悩みと されるしみやしわを予防したり改善する基剤が発見されてきている。重要なことは，これらの成分が皮䖉内の適切な 個所に供給されなければならない。またそれらの基剤には大気中で不安定な場合もある。乳化製剤はそれらのキャリ ヤーとしての役割を求められてきた。界面化学物性の利用や新規な機械を用いて多層エマルションやマイクロエマル ションが調製され，基荗の浸透性を向上させる期待が持たれている。 